\title{
Axonal Sprouting in Layer V Pyramidal Neurons of Chronically Injured Cerebral Cortex
}

\author{
Paul Salin,, ${ }^{1}$ Guo-Fang Tseng, ${ }^{2}$ Stuart Hoffman, ${ }^{3}$ Isabel Parada, ${ }^{4}$ and David A. Prince ${ }^{4}$ \\ 'Department of Pharmacology, University of California San Francisco, San Francisco, California 94143-0450, \\ 2Department of Anatomy, College of Medicine, National Taiwan University, Taipei, Taiwan 10018, ${ }^{3}$ Division of \\ Space Life Sciences, Universities Space Research Association, Houston, Texas 77058, and ${ }^{4}$ Department of \\ Neurology and Neurological Sciences, Stanford University School of Medicine, Stanford, California 94305-5300
}

\begin{abstract}
We performed experiments to determine whether axonal sprouting occurs in neurons of chronic neocortical epileptogenic lesions. Partially isolated somatosensory cortical islands with intact pial blood supply were prepared in mature rats. Neocortical slices from these lesions, studied 6$39 \mathrm{~d}$ later, generated spontaneous and/or evoked epileptiform field potentials (Prince and Tseng, 1993) during which neurons displayed prolonged polyphasic excitatory and inhibitory synaptic potentials/currents. Single electrophysiologically characterized layer $V$ pyramidal neurons in control and epileptogenic slices were filled with biocytin using sharp and patch-electrode techniques, their axonal arbors reconstructed and compared quantitatively. Neurons in injured cortex had a $56 \%$ increase in total axonal length, a $64 \%$ increase in the number of axonal collaterals and more than a doubling $(115 \%$ increase) of the number of axonal swellings. The presumed boutons were smaller and more closely spaced than those of control cells. In some neurons the main descending axon had hypertrophic segments from which branches arose. These highly significant changes were most marked in the perisomatic region of layer $V$. The axonal sprouting was associated with a decrease in somatic area but no significant change in dendritic arbors. Results suggest that a significant degree of axonal reorganization takes place in the chronically injured cortex where it might be an adaptive mechanism for recovery of function after injury, or might be maladaptive and play an important role in the generation of epileptiform events by increasing the numbers and density of synaptic contacts between neurons.
\end{abstract}

[Key words: axonal sprouting, epileptogenesis, neocortex, lesions, layer five, plasticity, pyramidal neurons, boutons]

Neocortical islands, chronically isolated from surrounding cortex and subcortical structures while maintaining an intact pial blood supply ("cortical isolations"), have long been a model of hy-

\footnotetext{
Received May 15, 1995; revised Aug. 11, 1995; accepted Aug. 15, 1995.

We thank E. Brooks and A. Haas-Johnson for help with illustrations and M. Canizares for preparing the manuscript. Support was provided by NIH Grants NS06477 and NS12151 from the NINDS, the Morris Research Fund, a Pimley Fellowship to G.-F.T., and a Fyssen Scholarship for P.A.S.

Correspondence should be addressed to David A. Prince, M.D., Department of Neurology and Neurological Sciences, Stanford University School of Medicine, Room M016, Stanford, CA 94305.

Copyright 1995 Society for Neuroscience 0270-6174/95/158231-12\$05.00/0
}

perexcitable, epileptogenic cortex (Echlin 1959, 1963; Sharpless and Halpern, 1962; Burns et al., 1979; see Halpern, 1972; Sharpless, 1964, for reviews). The transition from normal to abnormal cortical activity within chronically isolated cortex requires about 3 weeks to develop fully in the cat (Sharpless and Halpern, 1962), and various pathophysiological mechanisms have been proposed, including supersensilivity to the actions of $\mathrm{ACh}$ (Echlin, 1959; but see Reiffenstein and Triggle, 1972; Bird and Aghajanian, 1975); selective loss of inhibitory synapses (Ribak and Reiffenstein, 1982); and axonal sprouting of injured neurons with formation of new recurrent excitatory synapses (Purpura and Housepian, 1961). Recently, we have adapted this model of chronic epileptogenesis to the rat and guinea pig (Prince and Tseng, 1993; Hoffman et al., 1994) and have shown that epileptiform activity persists in neocortical slices from the partially isolated cortex maintained in vitro. Long latency evoked and spontaneous epileptiform events consisting of synchronous polyphasic field potentials that occur in an all-or-none fashion, and are associated with polysynaptic activities and repetitive spiking in neurons, have been recorded in slices beginning $\sim 7-14 \mathrm{~d}$ following the initial lesion. As is the case for chemically-induced epileptiform activity in neocortical slices (Connors, 1984; Hoffman and Prince, 1995), spontaneous and evoked interictal discharges in slices from partially isolated cortical slabs are initiated in layer V (Hoffman el al., 1994). We have also found that the area of chronic cortical injury generates more intense epileptiform activity than the contralateral homotopic cortex when high concentrations of the $\mathrm{GABA}_{\mathrm{A}}$ receptor blocker, bicuculline, are added to the perfusate (Hoffman et al., 1994), suggesting that factors other than disinhibition may play a role in the chronic epileptogenesis.

Since maladaptive axonal sprouting has been proposed as a mechanism underlying the development of epileptogenesis in isolated immature neocortex (Purpura and Housepian, 1961), following injury to the hippocampus in other animal models of epileptogenesis (Tauck and Nadler, 1985; Cronin and Dudek, 1988; Sutula et al., 1988, 1992; Mello et al., 1993; Represa et al., 1993), and in epileptic human temporal lobes (Babb et al., 1991, 1992; Masukawa et al., 1992; Isokawa et al., 1993), we performed experiments to examine the possibility that axonal sprouting might occur in mature neocortex among layer $\mathrm{V}$ pyramidal neurons that had been axotomized and deafferented as a result of partial cortical isolations. Neurons from injured and control cortex in animals of the same age were intracellularly filled with biocytin, allowing us to compare various features of 
Table 1. Cell groups 1-3 show the populations of neurons used to generate the data of Table 2 and Figures 5 and 8

\begin{tabular}{|c|c|c|c|c|c|}
\hline Cell group & $\begin{array}{l}\text { Soma width } \\
(\mu \mathrm{m})\end{array}$ & $\begin{array}{l}\text { Soma length } \\
(\mu \mathrm{m})\end{array}$ & $\begin{array}{l}\text { Soma ratio } \\
\text { (length/ } \\
\text { width) }\end{array}$ & $\begin{array}{l}\# \\
\text { Dendritic } \\
\text { tips }\end{array}$ & $\begin{array}{l}\text { Basal } \\
\text { dendritic } \\
\text { domain } \\
(\mu \mathrm{m})\end{array}$ \\
\hline 1. Undercut layer V $(n=8)$ & $16.8 \pm 2.9$ & $23.7 \pm 6.5$ & $1.5 \pm 0.5$ & $29 \pm 8$ & $392 \pm 44$ \\
\hline 2. Control layer $\mathrm{V}(n=7)$ & $19.3 \pm 2.5$ & $24 \perp 6.5$ & $1.3 \perp 0.2$ & $31 \perp 7$ & $398 \perp 49$ \\
\hline 3. Identified corticospinal $(n=3)$ & $17.9 \pm 3.5$ & $26.8 \pm 4.4$ & $1.5 \pm 0.4$ & $38 \pm 10$ & $416 \pm 91$ \\
\hline 4. Putative non-corticospinal ( $n=5$ & $17.6+0.3$ & $18.6+3.8$ & $1+0.1$ & $16+4$ & $215 \div 63$ \\
\hline
\end{tabular}

Basal dendritic domain: length of the longest dendritic process originating from the soma. Numbers are mean \pm

SEM.

their axonal arborization patterns quantitatively. This analysis identified several types of abnormality suggesting that axons of injured cells sprout collaterals which establish new intracortical connections within layer V. Such a response could serve as one mechanism for the development of epilepsy following cortical injury.

Portions of this work have been reported in an abstract (Salin et al., 1993).

\section{Materials and Methods}

Techniques for preparing partially isolated cortical islands in rodents have been described in detail elsewhere (Prince and Tseng, 1993; Hoff- man et al., 1994). Rats aged P21-P52 (P0 = date of birth) were anesthetized with pentobarbital $(55 \mathrm{mg} / \mathrm{kg}$ i.p.) and the somatosensory cortex exposed. In most animals a 30 gauge needle, bent at right angles 3 $\mathrm{mm}$ from its tip, was introduced just beneath and parallel to the pial surface, avoiding superficial blood vessels. The needle was then pushed down $2 \mathrm{~mm}$ through the cortex, rotated to make an undercutting lesion (see Fig. 1 of Hoffman et al., 1994), and removed by reversing these steps. In some animals, the needle was introduced in the same manner at an adjacent cortical site to achieve a more complete separation of the cortical island from surrounding tissue (Hoffman et al., 1994). In a few initial experiments the cortex was undercut with a small spatula introduced through a transcortical incision, carefully avoiding large vessels. Inspection of slices 2-3 weeks later or examination of cresyl violetstained fixed sections showed lesions consisting of white matter and

Table 2. Various parameters for groups of layer $\mathrm{V}$ neurons in undercut and control cortex

\begin{tabular}{|c|c|c|c|c|c|c|}
\hline$\underline{\text { ID\# }}$ & $\begin{array}{l}\text { Age at } \\
\text { surgery } \\
\text { (days) }\end{array}$ & $\begin{array}{l}\text { Age at } \\
\text { experiment } \\
\text { (days) }\end{array}$ & $\begin{array}{l}\text { Axonal } \\
\text { length } \\
(\mathrm{mm})\end{array}$ & $\begin{array}{l}\# \\
\text { Collaterals }\end{array}$ & $\begin{array}{l}\text { \# } \\
\text { Boutons }\end{array}$ & $\begin{array}{l}\text { Interbouton } \\
\text { distance } \\
(\mu \mathrm{m})\end{array}$ \\
\hline \multicolumn{7}{|l|}{ Undercut } \\
\hline U1 & 21 & 36 & 4.8 & 63 & 717 & 6.6 \\
\hline $\mathrm{U} 2$ & 21 & 36 & 2.9 & 36 & 355 & 8.1 \\
\hline U3 & 52 & 70 & 3.8 & 54 & 980 & 4.4 \\
\hline U4 & 29 & 35 & 11.1 & 93 & 2365 & 4.7 \\
\hline U5 & 45 & 84 & 7.4 & 60 & 1222 & 6.5 \\
\hline U6 & 21 & 37 & 3.5 & 50 & 906 & 4.3 \\
\hline $\mathrm{U7}$ & 22 & 38 & 4.8 & 44 & 1041 & 4.8 \\
\hline U8 & 21 & 36 & 4.1 & 48 & 891 & 4.6 \\
\hline Mean \pm SEM & $29 \pm 4,4$ & $\begin{array}{l}46.5 \pm 6.8 \\
\text { NS }\end{array}$ & $\begin{array}{l}5.3 \pm 1.0 \\
*\end{array}$ & $\begin{array}{l}56.0 \pm 6.1 \\
* * *\end{array}$ & $\begin{array}{l}1060 \pm 207 \\
* *\end{array}$ & $\begin{array}{l}5.5 \pm 0.49 \\
*\end{array}$ \\
\hline \multicolumn{7}{|l|}{ Control } \\
\hline $\mathrm{Cl}$ & $\mathrm{n} / \mathrm{a}$ & 45 & 2.8 & 25 & 304 & 9 \\
\hline $\mathrm{C} 2$ & $\mathrm{n} / \mathrm{a}$ & 31 & 2.7 & 23 & 279 & 7.9 \\
\hline $\mathrm{C} 3$ & $\mathrm{n} / \mathrm{a}$ & 38 & 2.6 & 32 & 464 & 5.7 \\
\hline $\mathrm{C} 4$ & $\mathrm{n} / \mathrm{a}$ & 28 & 2.2 & 30 & 432 & 7.9 \\
\hline $\mathrm{C} 5$ & $\mathrm{n} / \mathrm{a}$ & 38 & 2.0 & 41 & 392 & 5.0 \\
\hline $\mathrm{C} 6$ & $\mathrm{n} / \mathrm{a}$ & 34 & 5.7 & 57 & 885 & 6.7 \\
\hline $\mathrm{C} 7$ & $\mathrm{n} / \mathrm{a}$ & 38 & 4.8 & 37 & $\mathrm{n} / \mathrm{a}$ & $\mathrm{n} / \mathrm{a}$ \\
\hline $\mathrm{C} 8$ & $\mathrm{n} / \mathrm{a}$ & 35 & 4.5 & 30 & 652 & 7.8 \\
\hline $\mathrm{CP}$ & $\mathrm{n} / \mathrm{a}$ & 36 & 2.7 & 22 & 452 & 5.6 \\
\hline $\mathrm{C} 10$ & $\mathrm{n} / \mathrm{a}$ & 34 & 3.5 & 44 & 585 & 7.1 \\
\hline Mean \pm SEM & $\mathrm{n} / \mathrm{a}$ & $35.7 \pm 1.5$ & $3.4 \pm 0.4$ & $34.1 \pm 3.4$ & $494 \pm 63$ & $7.0 \pm 0.44$ \\
\hline
\end{tabular}

Age at surgery: age of rat at time that the cortical isolation was prepared. Age at experiment: age at terminal slice experiment. Axonal length: total length of main axon and all of its branches measured from two-dimensional camera lucida reconstructions. \# Collaterals: total number of axonal branches. \# Boutons: total number of axonal swellings. Interbouton distance: mean distance between presumed boutons. $\mathrm{n} / \mathrm{a}$, not applicable. ${ }^{*}, p<0.05$ for axonal length and interbouton distance in undercut versus control neurons. $* *, p<0.006$ for number of boutons in undercut versus control neurons. ***, $p<0.004$ for number of collaterals in undercut versus control neurons. Two-tailed Mann-Whitney $U$ test. 

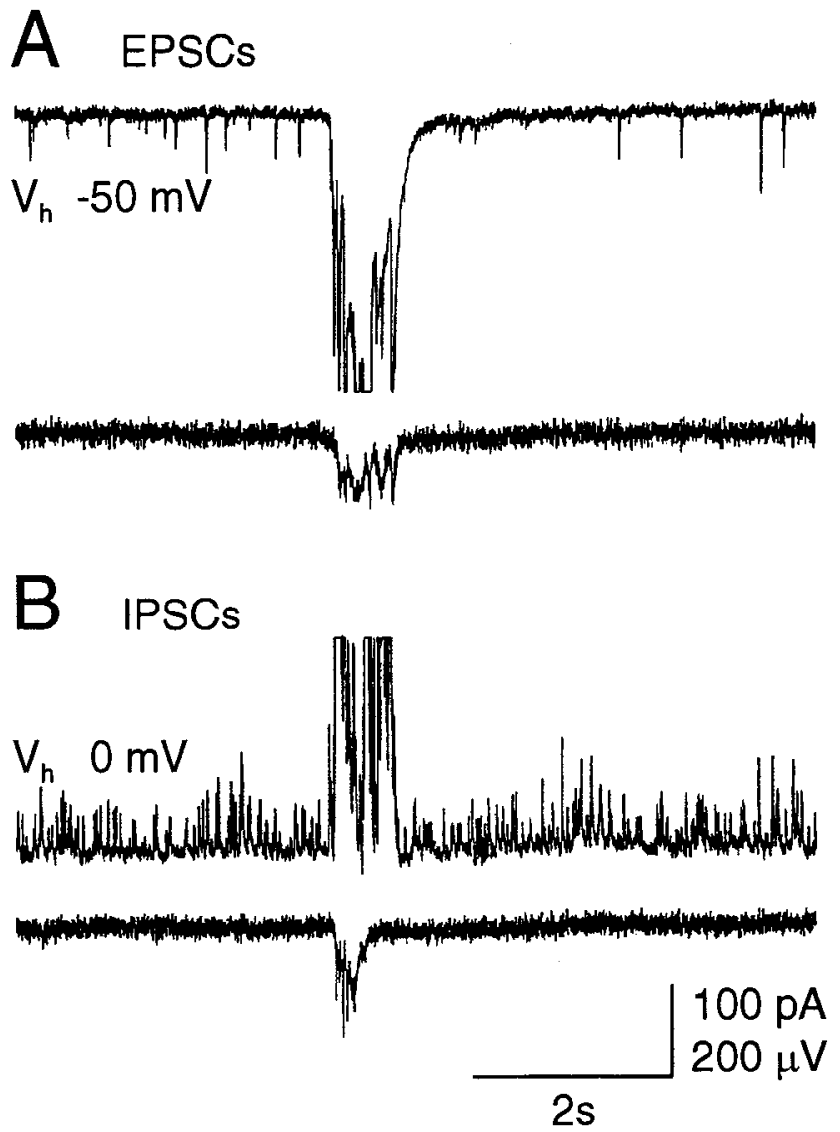

Figure 1. Representative whole cell voltage-clamp recordings from neuron in injured cortex in which spontaneous epileptiform events were occurring. Upper traces, voltagc-clamp rccords from pyramidal ncuron. Lower traces, extracellular field potential, negativity down. A, With holding potential $\left(V_{h}\right)=-50 \mathrm{mV}$, spontaneous inward currents occur and field potential interictal event is associated with a large multiphasic inward current lasting about $780 \mathrm{msec}$. $B$, With $V_{h}=0 \mathrm{mV}$, only spontaneous outward currents are seen and epileptiform field potential is associated with a large amplitude multiphasic outward current. Excitatory postsynaptic currents (EPSCs) and inhibitory postsynaptic currents (IPSCs) are clipped at their peaks during the epileptiform events. Field potentials in $A$ and $B$ contain bursts of unit activity during interictal discharges.

transcortical cuts (see Fig. $2 A$ ). The exposed cortex was covered with gelfoam or Saran Wrap, the wound closed and animals allowed to recover. Six to 39 d later (mean: $17.5 \pm 3.3 \mathrm{~d}$ ) rats were deeply anesthetized with pentobarbital $(55 \mathrm{mg} / \mathrm{kg}$ i.p.) and decapitated. Brains were removed and immersed in cold $\left(5^{\circ} \mathrm{C}\right)$ modified Ringer's solution containing (in mM): 230 sucrose, $10 \mathrm{MgSO}_{4}, 0.5 \mathrm{CaCl}_{2}, 1.25 \mathrm{NaH}_{2} \mathrm{PO}_{4}, 2.5$ $\mathrm{KCl}, 26 \mathrm{NaHCO}_{3}$, and 10 glucose (Fukuda and Prince, 1992). A block of somatosensory cortex containing the previously made lesion was glued to the stage of a vibratome (Lancer series 1000) with cyanoacrylate cement and $400 \mu \mathrm{m}$ thick coronal slices cut in the above solution. The slices were then incubated in standard perfusion solution $\left(32^{\circ} \mathrm{C}\right)$ that contained (in mM) $124 \mathrm{NaCl}, 5 \mathrm{KCl}, 26 \mathrm{NaHCO}_{3}, 2 \mathrm{CaCl}_{2}, 2$ $\mathrm{MgCl}_{2}, 1.25 \mathrm{NaII}_{2} \mathrm{PO}_{4}$, and 10 glucose; pII $=7.4$ when saturated with $95 \% \mathrm{O}_{2}$ and $5 \% \mathrm{CO}_{2}$. Recordings were made after at least $1 \mathrm{hr}$ of incubation. Neocortical slices were minimally submerged, or maintained in an interface-type chamber at $34-35^{\circ} \mathrm{C}$. Intracellular recordings were made using either sharp electrodes filled with KAc $(2 \mathrm{M})$ and $1 \%$ biocytin (100-125 $\mathrm{M} \Omega$ ), or patch-electrodes that had resistances of 4-6 MS when filled with intracellular solution containing (in $\mathrm{mM}$ ): $120 \mathrm{Cs}-$ gluconate, $10 \mathrm{HEPES}, 11 \mathrm{EGTA}, 1 \mathrm{CaCl}_{2}, 2 \mathrm{MgCl}_{2}, 5 \mathrm{QX} 314$ (Astra), and $0.5 \%$ biocytin; $\mathrm{pH}=7.2$.

Both sharp and patch-electrodes were positioned in layer $\mathrm{V}$, about halfway through the slice to minimize the effects of the slice procedure on the filled axonal arbors. Once a satisfactory impalement was made with a sharp electrode, spontaneous and evoked activities were recorded using stimuli applied to bipolar tungsten electrodes situated at the pial surface or the junction of layer VI and white matter, just above the area of the undercut. After electrophysiological recordings were complete, the neuron was filled iontophoretically with biocytin using parameters previously described (Tseng et al., 1991). Patch pipettes were advanced through the slice while applying a small positive pressure and gigaohm seals obtained (Blanton et al., 1989). Once the whole cell recording mode was achieved, spontaneous and evoked activities were recorded. Biocytin apparently diffused easily into the neuron and its processes, since excellent "fills" were obtained following 15-30 min. whole cell recordings. The method used to obtain recordings and fill neurons had no bearing on the results presented below.

Slices containing biocytin-filled cells were fixed in $4 \%$ paraformaldehyde in $0.1 \mathrm{M}$ phosphate buffer overnight and then sectioned at 80 $\mu \mathrm{m}$. The fixed sections were processed with the avidin-biotin-peroxidase method as described elsewhere (Horikawa and Armstrong, 1988; Tseng et al., 1991). Cortical layers were identified under bright-field illumination or by staining adjacent sections with cresyl violet or cytochrome oxidase. The filled layer $\mathrm{V}$ pyramidal neurons were reconstructed in two dimensions ( $x-y$ plane) with a camera lucida using a Hoffman water-immersion $50 \times$ or an oil immersion $100 \times$ objective. To improve the accuracy of measurements, the camera lucida tracings were enlarged on a photocopier $\sim 2.4 \times$. Axonal lengths, numbers of axonal branches, numbers and perimeters of presumed boutons and the distances between boutons were then measured and quantitated using a digitization tablet and SIGMASCAN software (Jandel Scientific) coupled to a 80486 IBM AT compatible computer. Since the lesion was obvious on the mounted section, it was impossible to blind the observer. Reliability was checked by having some measurements and counts from the same neuron made by two investigators, or by having the same observer make measurements from the same neuron twice. Results of these maneuvers suggested that the data obtained were reproducible. The number of axonal or dendritic branches in various laminae was estimated from a modified version of the Sholl analysis (Sholl, 1956) by counting the number of crossings made by a series of lines spaced $80 \mu \mathrm{m}$ apart, placed parallel to the pial surface over the camera lucida drawings. Statistical significance between groups was determined using a twotailed Mann-Whitney $U$ test (criterion $p<0.05$ ). Data are expressed as mean \pm SEM except where indicated.

\section{Results}

Patch-clamp or sharp electrode recordings were obtained from 91 biocytin-labeled layer $\mathrm{V}$ pyramidal cells, of which 52 were from control cortex and 39 from partially isolated epileptogenic cortex. Of these, 8 neurons from injured cortex $(5$ patch and 3 sharp electrode recordings) in 8 slices from 8 animals, and 10 neurons from normal control cortex (7 patch and 3 sharp electrode recordings) at similar ages, including 3 identified corticospinal cells, were selected for analysis (Tables 1,2 ). One additional neuron was used only for measurements of bouton size (below) and is not shown in the tables. The following criteria were used to select neurons for analysis.

(1) All pyramidal neurons from injured cortex came from slices in which typical epileptiform field potentials and cellular discharges could be evoked by extracellular stimuli, or occurred spontaneously (Fig. 1). Evoked field potentials consisted of an initial short latency event followed by a variable latency, all-ornone polyphasic discharge which might last several hundred milliseconds. Current-clamp records showed that these extracellular potentials usually corresponded closely to intracellular polysynaptic events and repetitive spike activity (not shown; see Prince and Tseng, 1993). Voltage-clamp recordings with the membrane potential held near the expected $\mathrm{Cl}^{-}$equilibrium potential $(-60$ $\mathrm{mV}$ ) revealed that epileptiform field potentials in all patch-clamp recordings were associated with irregular polyphasic excitatory postsynaptic currents that often had a time course very similar to the extracellular activities (Fig. $1 A$ ). When the holding potential was adjusted to be near the expected equilibrium potential 

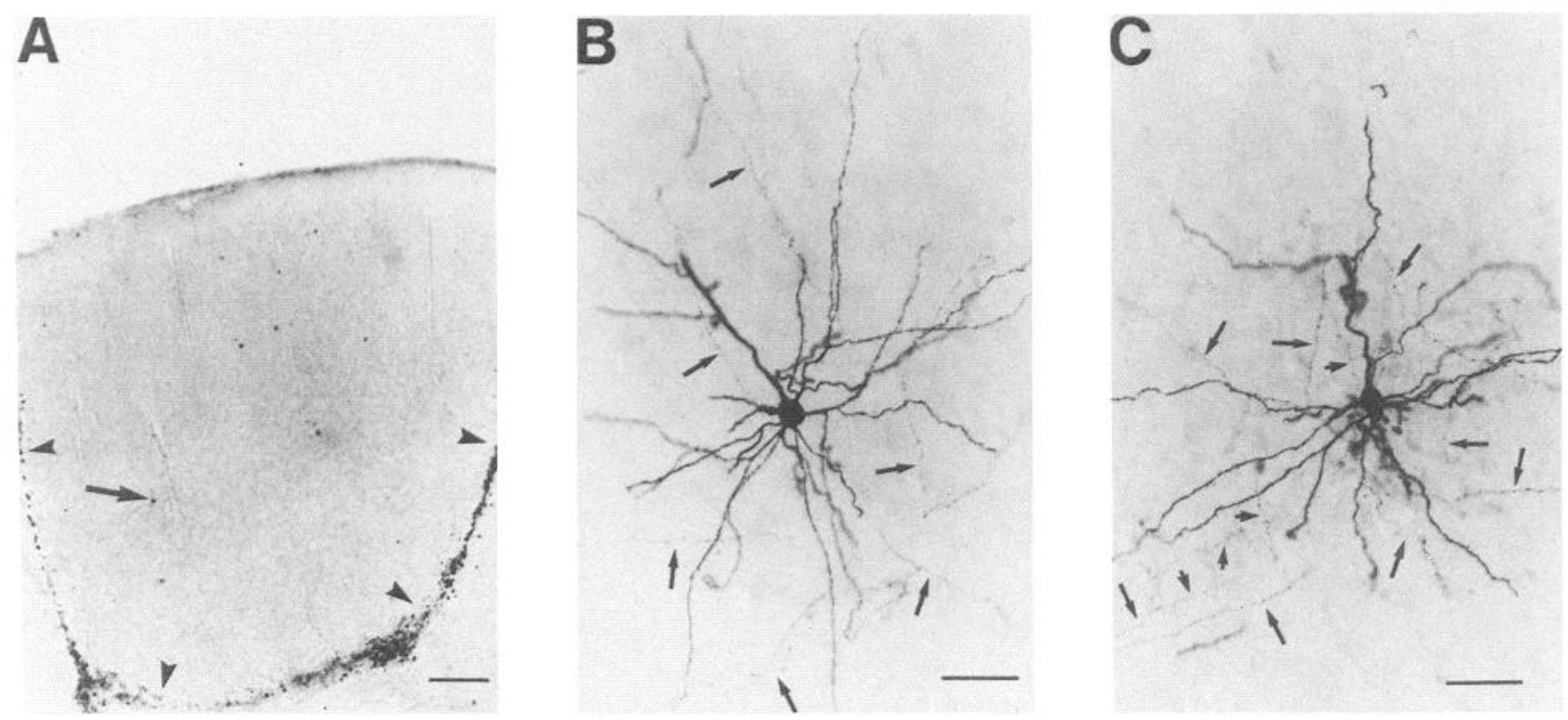

Figure 2. A, Photomicrograph showing margins of cortical isolation made 3 weeks prior to the terminal experiment (arrowheads). Arrow points to biocytin filled neuron. B, Representative photomicrograph of a control layer V pyramidal neuron (cell C4 of Table 2) filled with biocytin. Portions of the apical dendritic tree are present in other sections. Arrows, Axonal branches. $C$, Biocytin-filled layer V pyramidal neuron from undercut cortex (cell U6 of Table 2). Arrows, Axonal branches. Dark area about $75 \mu \mathrm{m}$ from soma along apical dendrite is dendritic branch, out of focus, extending in the z-axis. Scale bars: $A, 200 \mu \mathrm{m} ; B$ and $C, 50 \mu \mathrm{m}$.

for excitatory synaptic events (ca. $0 \mathrm{mV}$ ), a barrage of inhibitory postsynaptic currents was recorded during the evoked epileptiform discharge (Fig. $1 B$ ).

(2) A second criterion was the completeness of the biocytin fill. Only pyramidal neurons that had well-developed dendritic arbors with spines, soma positions in layer $\mathrm{V}$ about midway through the thickness of the slice, and well-filled axonal arbors were selected for analysis. Instances in which more than one neuron was labelled following a single "fill" were rare and these filled neurons were not used in the analysis.

(3) Since layer V pyramidal neurons are known to have a variety of axonal arbors (e.g., Burkhalter and Charles, 1990; Chagnac-Amitai et al., 1990), we applied several anatomic criteria to facilitate selection of a relatively homogenous population of injured and control neurons, including a ratio of soma length to width of approximately 1.5 , a large number of basal dendritic tips, a large basal dendritic domain, and a thick apical dendrite that reached layer I. Table 1 summarizes the measurements of somata and dendrites of the injured (group 1) and control groups (groups 2 and 3 ) and shows that the above parameters were comparable in the three groups of neurons used in this analysis. The fourth group, that was not included, contained neurons with smaller, more round somata, fewer basal dendritic tips and a smaller basal dendritic domain. In 5 of 8 neurons from injured cortex the main axon could be traced to the site of the undercutting lesion. The identified corticospinal neurons of group 3 were obtained using a double labelling technique as previously described (Tseng et al., 1991).

Photomicrographs of biocytin-filled neurons in undercut epileptogenic and control cortex are shown in Figures 2 and 3, and cameral lucida reconstructions of representative cells in Figure 4. Several differences became apparent in comparing injured and control neurons. First, the injured cells appeared to have a more extensive plexus of axonal branches, particularly in layer $\mathrm{V}$, near the soma (Figs. $2 C$, arrows; Fig. $4 A$ ). This was much more apparent in cameral lucida reconstructions than photographs of sin- gle sections, since it was difficult to capture significant extents of axons in any one focal plane. The results of a modified Sholl analysis for the neurons of Figure 4, $A l$ and $B I$ are shown in Figure 4, $A 2$ and $B 2$, respectively. The large number of axonal branches in the neuron of Figure $4 A I$ are most prominent in layer $\mathrm{V}$ near the soma, but also extend into supragranular layers. In contrast, the double-labeled corticospinal neuron of Figure $4 B 2$ has a more limited axonal arbor in layers V and VI. In 4 injured neurons, the main descending axon had 1 or more sausage-like enlargements from which collateral branches (Fig. $3 E$, arrowheads), or what appeared to be abortive sprouts (Fig. $3 A$, arrow), might arise. These hypertrophic segments resembled those reported by Ramon y Cajal (1928a,b) in undercut, immature cortex and by Purpura and Housepian (1961) in Golgi studies of chronically isolated kitten cortex. In addition, some axons of injured pyramidal neurons had a "terminal club" or "retraction ball" located within the substance of the slice (Fig. 3B) (Ramon y Cajal, 1928a,b). All axons had small (2-9 $\mu \mathrm{m}$ diameter) swellings along their course (arrows in Fig. $3 C, D$ ) which will be termed "boutons" in the remainder of this article, although we recognize that EM corroboration is required to verify this assumption (e.g., Havton and Kellerth, 1987; Lagerback et al., 1981). There appeared to be a significant difference in the boutons on axons of injured versus control neurons ramifying in layer $\mathrm{V}$, in that boutons of injured neurons were smaller and more numerous (cf. Fig. $3 C, D$ ).

In order to further evaluate these possible differences between control and injured neurons, we quantitated several parameters of the camera lucida drawings. Data obtained from reconstructions such as those of Figure 4 are shown in Table 2. The total axonal length, measured in 8 neurons from undercut cortex (5.3 $\pm 1.0 \mathrm{~mm}$; range $2.9-11.1 \mathrm{~mm}$ ) was significantly greater than that of 10 control layer $\mathrm{V}$ pyramidal neurons $(3.4 \pm 0.4 \mathrm{~mm}$; range $2.0-5.7 \mathrm{~mm} ; p<0.05$ ). Injured neurons also had a larger number of collateral axonal branches than control cells $(56.0 \pm$ 6.1 vs $34.1 \pm 3.4 ; p<0.004)$. A highly significant difference 

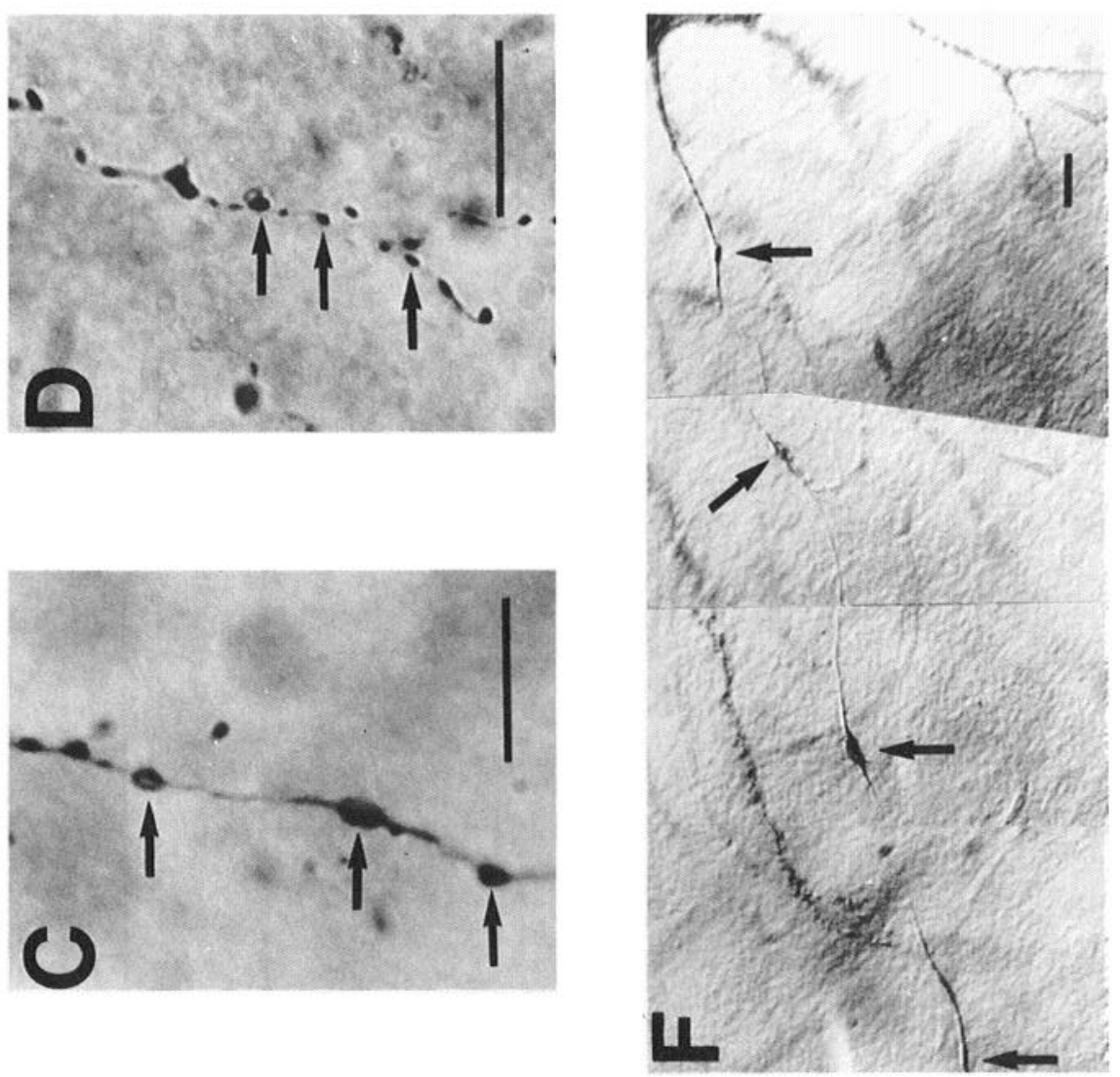

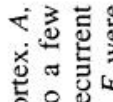

웡

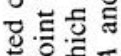

흔

高

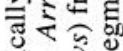

ติ

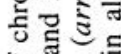

पे

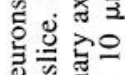

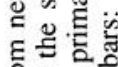

놀 응

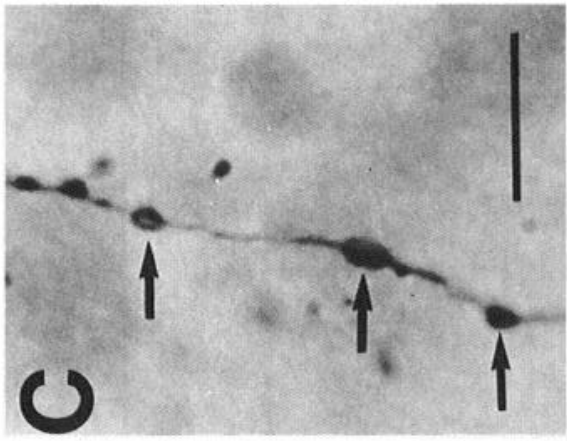

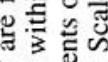

啳

플등

든 흥

政

s

o

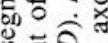

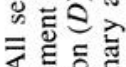

क 인. 톰

인

퓰 엘
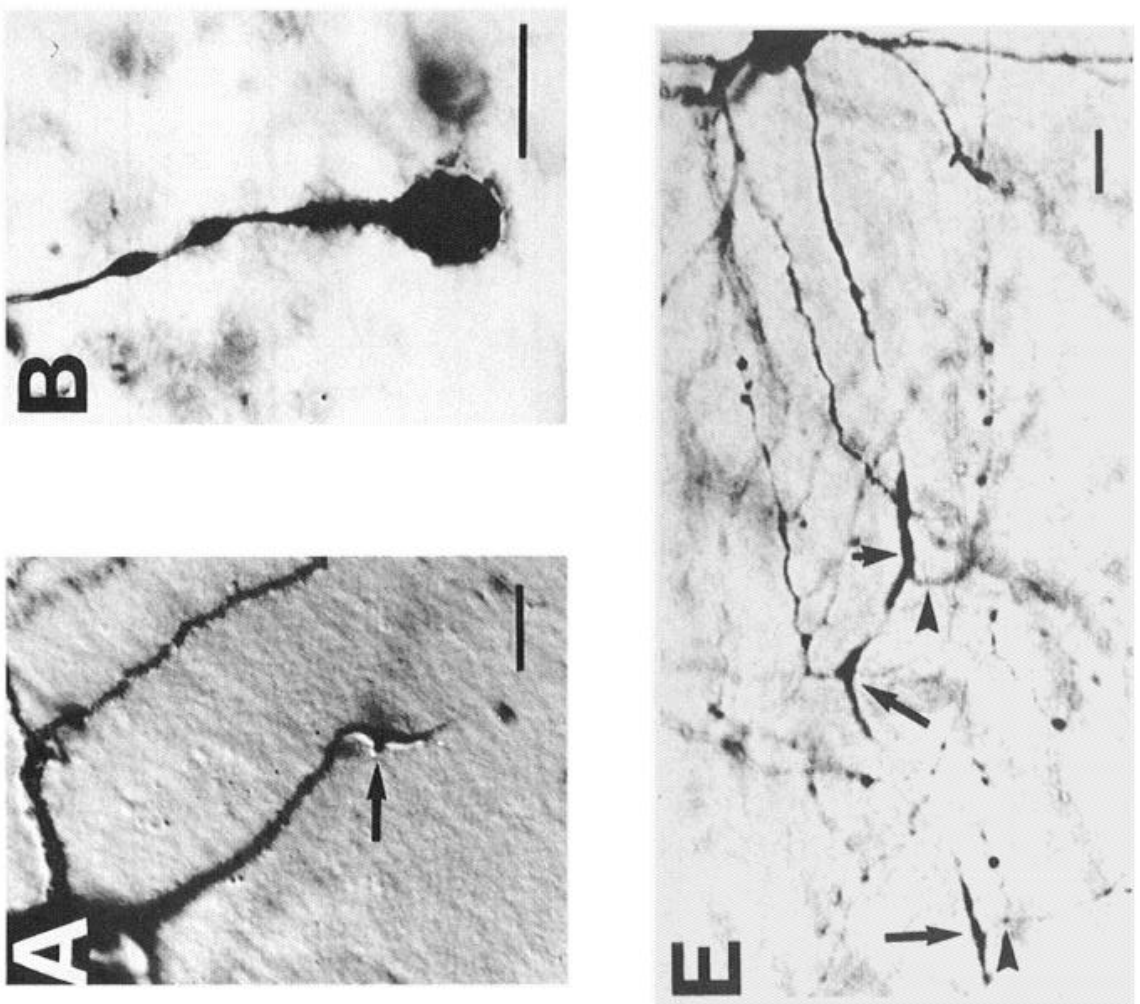

졸 를 응

है․․․

ล․

$>$ oi

製造

京

西 可

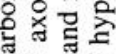

ส ํํํ

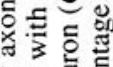

ธั 웛

है. 등

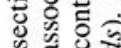

․․

นิำ

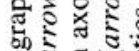

잉

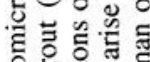

胡的

ज西

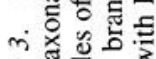

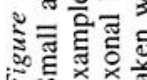



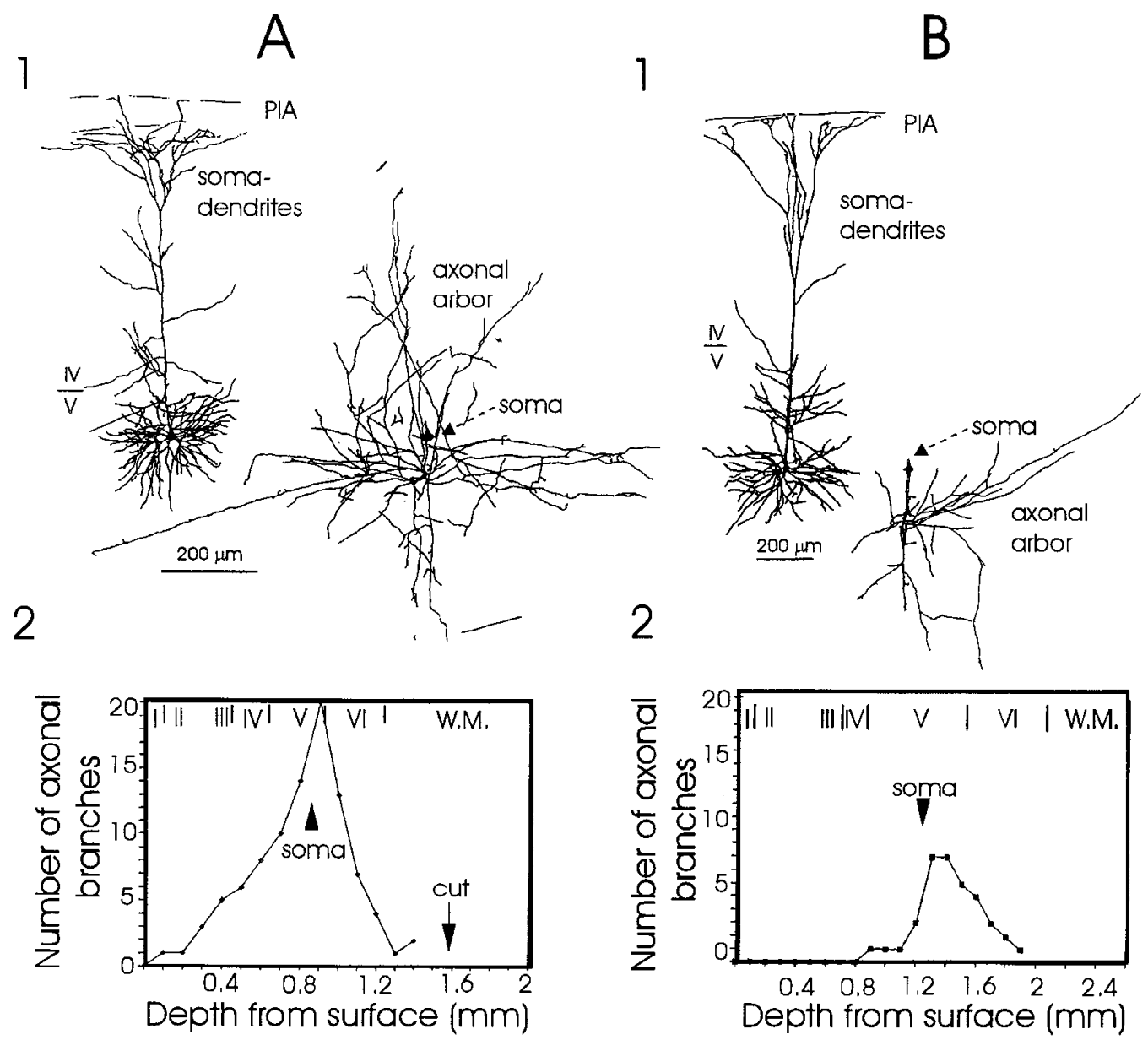

Figure 4. Camera lucida drawings from a layer V neuron of undercut cortex (A, cell U4 of Table 2) and an identified double-labeled corticospinal cell from control cortex $(B$, cell $C 3$ of Table 2 ). The axon of the cell in $A$ extends to the subcortical cut. Drawing to the left for each cell shows the soma-dendritic tree. Drawing to the right shows the soma and axonal arborization. $A 2$ and $B 2$, Modified Sholl analysis showing number of axonal branches intersected by lines drawn parallel to the pia through different laminae. Arrowheads mark positions of somata. I-VI, Cortical layers I-VI. W.M., White matter; PIA, pial surface; CUT, site of undercutting lesion. Cell of $B$ has a more limited axonal arbor, restricted to layers V and VI.

between control and injured neurons was also evident when the total numbers of boutons were counted. Injured neurons had more than twice as many boutons as control cells (1060 \pm 207 vs $494 \pm 63 ; p<0.006$ ). There was also a decreased distance between boutons in injured $(5.5 \pm 0.49 \mu \mathrm{m})$ versus control neurons $(7.0 \pm 0.44 \mu \mathrm{m} ; p<0.05)$. There was no apparent correlation between these parameters and either the age of the animals at initial surgery or the age at the terminal experiment (Table 2). It is of interest that the neuron with the largest axonal arbor was studied $6 \mathrm{~d}$ after the initial lesion.

An additional finding suggested that the presumed contacts made by injured cells might be anatomically different from those of normal neurons. By enlarging the drawings of boutons it was possible to estimate their size in control and injured cells (Fig. 5). Figure $5 A$ shows representative histograms of the perimeters of boutons found within $100 \mu \mathrm{m}$ of the center of the soma in 1 control and $l$ injured neuron. Boutons in control cells had a significantly larger mean perimeter and a much larger range of perimeter sizes (5.3 $\pm 0.4 \mu \mathrm{m}$, SEM; range 4.1-8.2 $\mu \mathrm{m}, n=8$ ) than neurons in the undercut cortex $(2.7 \pm 0.2 \mu \mathrm{m}$; range $2.3-$ $4.5 \mu \mathrm{mI} ; p<0.0006$ ). The cumulative probability plot of Figure $5 B$ confirms the highly significant difference in bouton sizes.

Further analysis of the boutons in camera lucida reconstruc- tions of neurons from undercut and control cortex was done by drawing a series of lines $80 \mu \mathrm{m}$ apart parallel to the pia and counting the numbers of swellings in each compartment. This analysis revealed that the numbers of boutons of injured neurons increased versus control cells starting about $500 \mu \mathrm{m}$ below the pial surface, and that the difference between neurons in the undercut and control cortices became highly significant in layer $\mathrm{V}$, about $1120 \mu \mathrm{m}$ from the pial surface, near the somata of the injured neurons (Fig. 6A; $p<0.02$ ). The modified Sholl analysis of Figure $6 B$ shows that there were also significant increases in numbers of axonal branches in layer $V$ from about 1120-1280 $\mu \mathrm{m}$ below the pial surface. The depths at which there were an increased number of boutons coincided approximately with those where there were significant increases in the numbers of branches (cf. Figs. 6A, $B$ ).

The plots of Figure 7 provide a two-dimensional view of the density and distribution of boutons in two reconstructed control and two injured neurons, as seen from the slice surface. These were obtained by superimposing the boutons from all sections for each neuron. Control and injured cells with the smallest and least dense "field" of boutons (control cell in Fig. 7AI and injured cell in Fig. 7B2) and the most extensive and densest field of swellings (control cell in Fig. 7A2 and injured cell in Fig. 

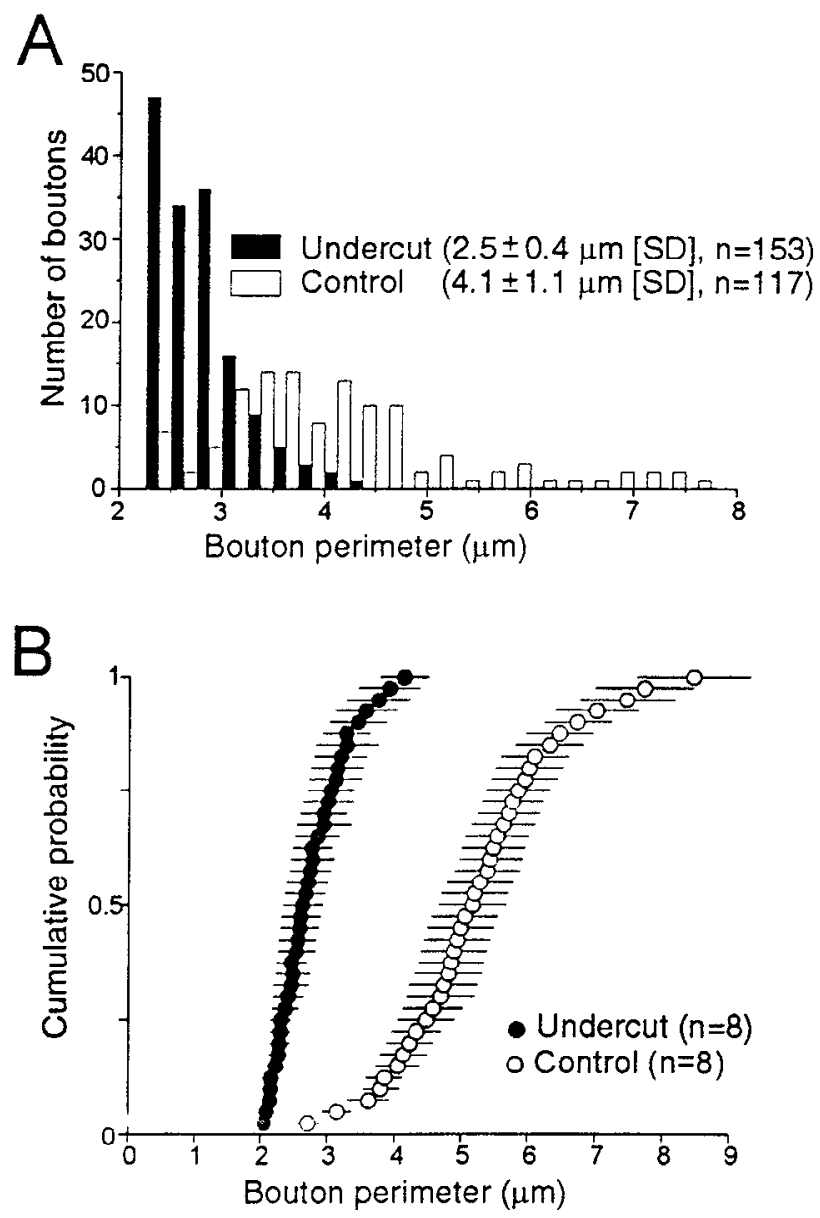

Figure 5. Analysis of the bouton size. A, Histogram of the distribution of bouton perimeters for 1 neuron from undercut and 1 control neuron. $n=$ number of boutons measured. $B$, Cumulative probability plot of bouton perimeters for eight control and eight undercut neurons. The perimeters were averaged at each $2.5 \%$. Horizontal bars are \pm SEM.

$7 B 1$ ) were selected for this illustration from a total of 6 control and 6 injured neurons analyzed in this way. The density of boutons was highest in the perisomatic area within layer $\mathrm{V}$ in control neurons and just deep to the level of the soma in the injured cells. Further, there were larger areas of higher bouton density in the plots from injured cells, as well as zones in which the density of boutons $\left(76-100 / 6400 \mu \mathrm{m}^{2}\right)$ exceeded that found in any of the control cells. The injured neuron with the most limited field of boutons had a more extensive area of high density bouton distribution than the control neuron with the largest field of boutons (cf. plots of Fig. 7A2,B2). The prominent extension of the field of boutons toward the pial surface, seen in some injured neurons (Fig. 7BI), was also unusual in another population of control cells (Tseng and Prince, 1993).

Because of reports of changes in dendrites of cortical neurons following deafferentation and cortical injury (Nitsch and Frotscher, 1991; Jones and Schallert, 1992), we also performed a modified Sholl analysis of the number of dendritic branches in control versus injured neurons. Results shown in Figure 8 indicate that there may be a decrease in the number of apical and basilar dendritic branches of injured layer $\mathrm{V}$ neurons, as might be predicted from a reduction in inputs due to deafferentation; however this does not reach statistical significance. Somatic areas were measured in the control and injured neurons of groups 1-3 in Table 1 plus additional neurons whose axonal arbors were not adequately filled. Soma size of injured neurons (200 $\pm 15 \mu^{2}, n=19$ ) was significantly less than in control layer $\mathrm{V}$ cells $\left(266 \pm 19 \mu \mathrm{m}^{2}, n=33 ; p<0.025\right)$. Thus, the increase in axonal lengths and numbers of branches was not associated with a similar phenomenon in dendrites, or with enlargement of somata. The chronic injury decreased somatic size and may have resulted in a small decrease in the numbers of dendritic branches while the axonal arborization and its contacts with other neurons were increasing.

\section{Discussion}

The results of these experiments suggest that epileptogenesis, together with a significant reorganization of intracortical connectivity occurs in mature animals following local cortical trauma. The lesions used would be expected to interrupt subcortical afferents, axotomize cortical output neurons in layers V and VI, disrupt intracortical connectivity, and result in death of some neurons immediately adjacent to the subcortical and intracortical cuts. Any or all of these features of the injury might have served as stimuli for inducing changes in axonal arbors of layer $\mathrm{V}$ pyramidal neurons. The combination of a highly significant increase in total axonal length, numbers of branches, and numbers and density of presumed boutons, mostly in layer $\mathrm{V}$, together with the presence of hypertrophic changes in the main descending axon from which axonal branches appeared to arise, all strongly suggest that a significant axonal sprouting reaction has taken place. Although it is likely that most of these changes are regenerative, hypertrophic axonal segments and retraction balls or clubs similar to those secn in Figure $3, B$ and $E$, were described by Ramon y Cajal in tissue obtained hours or a few days after cortical wounds, and regarded as part of the degenerative reaction (Ramon y Cajal, 1928a). The anatomic heterogeneity of unidentified layer V cortical pyramidal neurons (e.g., Chagnac Amitai et al., 1990; Larkman and Mason, 1990) contributes to the difficulty in comparing structural features of groups of these cells, as is required in experiments such as those reported here. Differences might be expected even within the same class of projection cells (e.g., Ojima et al., 1992; Tseng and Prince. 1993). The anatomic selection criteria (Table 1 and Results) did allow us to eliminate a group of neurons that were clearly different anatomically (Group 4 of Table 1), but certainly did not result in perfectly comparable groups of control and injured neurons. Nonetheless, the differences between axons in experimental and control groups were qualitatively (e.g., bouton size; hypertrophic swellings), as well as quantitatively substantial (Table 2 ), and unlikely to have occurred by chance selection of unrepresentative controls. The mechanisms whereby partial isolations lead to plastic anatomic changes in layer $\mathrm{V}$ neurons are unknown, however injury to CNS neurons, as well as epileptiform activity itself, does induce the expression of a variety of mRNAs for immediate early genes, trophic factors and their receptors and cystoskeletal proteins which may be involved (Dragunow et al., 1990; Sharp et al., 1990; Ernfors et al., 1991; Mikucki and Oblinger, 1991; Tetzlaff et al., 1991; Gall, 1992, 1993; Herdegen et al., 1993; Lapchak et al., 1993; Merlio et al., 1993).

Following early demonstrations of sprouting and formation of new synapses in subcortical structures (Liu and Chambers, 1958, Raisman, 1969), it has become clear that there can be extensive postlesional axonal sprouting in cerebral cortex. The experiments reported here, however, are the first to directly address 


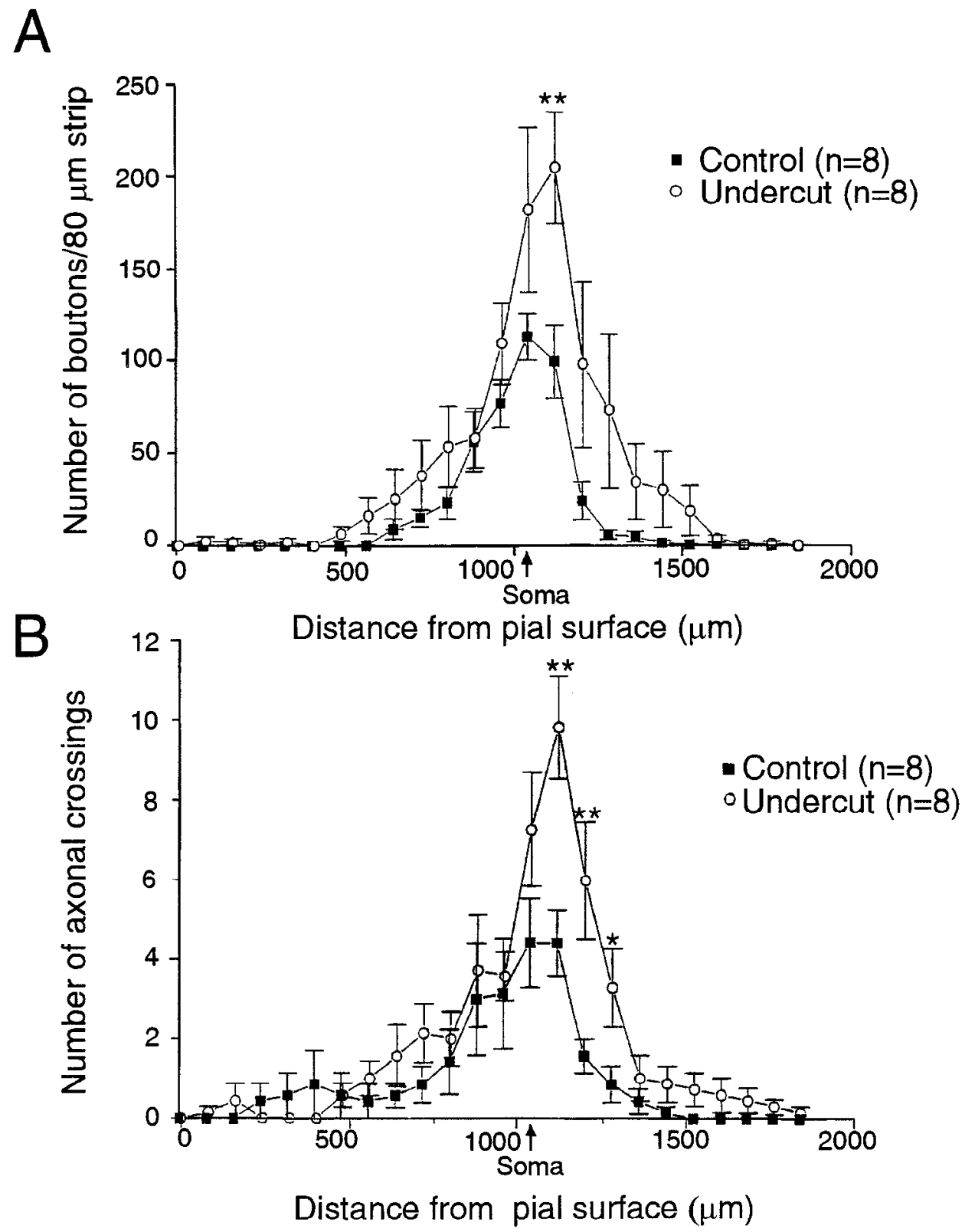

Figure 6. A, Numbers of bouton in 80 $\mu \mathrm{m}$ strips of cortex parallel to the pia at varying distances from the pial surface. Control, $n=8$; Undercut, $n=8$. $B$, Modified Sholl analysis of the numbers of axonal crossings at various distances from the pial surface. Control, $n$ $=8$; Undercut, $n=8 . *, p<0.01$; **, $p<0.005$.

the issue of intracortical axonal sprouting and quantitate the parameters of sprouting in an identified population of neocortical ncurons. Most studies have focused on the sprouting phenomenon in the hippocampus (Lynch et al., 1973; Lynch and Cotman, 1975; Matthews et al., 1976). The capacity of neocortical output neurons to modify their extracortical axonal arborizations has been demonstrated following a variety of cortical and subcortical lesions (Tsukahara et al., 1975; Villablanca et al., 1988; Kuang and Kalil, 1990). Other studies show that lesions along afferent pathways can induce presumed sprouting of intrinsic cortical axons (Westenbroek et al., 1988; Keller et al., 1990; Dunn-Meynell et al., 1992; Darian-Smith and Gilbert, 1994). Direct trauma to the cortex is also an effective stimulus for sprouting (Maxwell et al., 1990; Fishman and Mattu, 1993; Masliah et al., 1993) and cortical neuronal sprouting may also take place in human pathological processes such as Alzheimer's disease (Ihara, 1988). Some of these sprouting responses are transient and diminish during the time course of the experiment (Fishman and Mattu, 1993; Masliah et al., 1993). Since our experiments were only done from 6-39 $\mathrm{d}$ following the intracortical lesion, the time required for initiation of axonal sprouting, or its degree of persistence in this model are unknown. The latency to onset of hyperexcitability in slices from partially isolated, mature cortex (7-14 d postlesion; Hoffman et al., 1994) and the presence of sprouting in layer $\mathrm{V}$ neurons at the earliest times examined, are compatible with the time course of sprouting induced by lesions in hippocampus (Matthews et al., 1976) and neocortex (Fishman and Mattu, 1993; Masliah et al., 1993).

Purpura and Housepian (1961) made lesions similar to those used in these experiments in neocortex of young kittens and reported that after 2-9 d there was an apparent increase in recurrent axonal collaterals of pyramidal neurons, resembling that reported by Ramon y Cajal (1928). It was suggested that functional excitatory contacts made by these new axons might be responsible for epileptiform activities evoked in the partially isolated immature cortex by direct cortical stimulation in vivo. Subsequent Golgi studies of partially isolated cat cortex from animals lesioned as adults (Rutledge et al., 1969, 1972) or while 


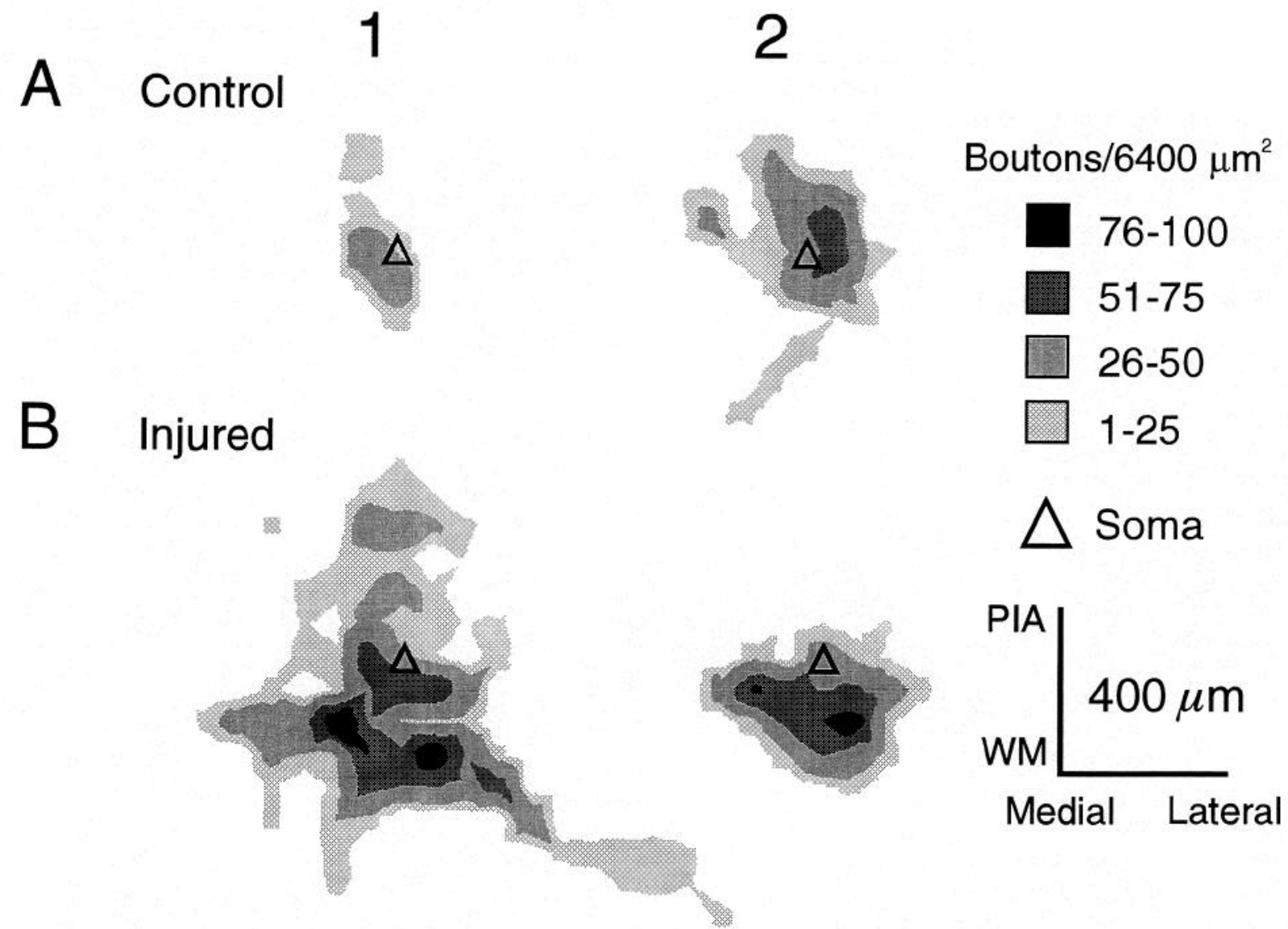

Figure 7. Two-dimensional projection of bouton distribution and density for two control $(A)$ and two injured $(B)$ neurons. Scale at right indicates densities for various shadings. Triangles, Location of somata in layer V. Soma depths below pial surface: $A 1,1480 \mu \mathrm{m} ; A 2,1340 \mu \mathrm{m} ; B 1,1320$ $\mu \mathrm{m} ; B 2,1240 \mu \mathrm{m}$.

immature (Rutledge et al., 1972) lead to the conclusions that axonal collateral proliferation found in immature cortex did not persist or occur in the mature brain, and therefore was not a factor in the development of epileptiform activity. These experiments focused predominantly on layer II/III cells with very in- completely stained axonal arbors and were therefore technically inadequate to address quantitatively the issue of possible sprouting of layer $\mathrm{V}$ neurons.

Without ultrastructural studies it is not possible to determine whether the small boutons (Fig. 5) mark areas of new synaptic
Figure 8. Sholl analysis of dendritic branches of eight control neurons and eight neurons from undercut cortex. Differences in numbers of basal and apical dendritic branches did not reach statistical significance.

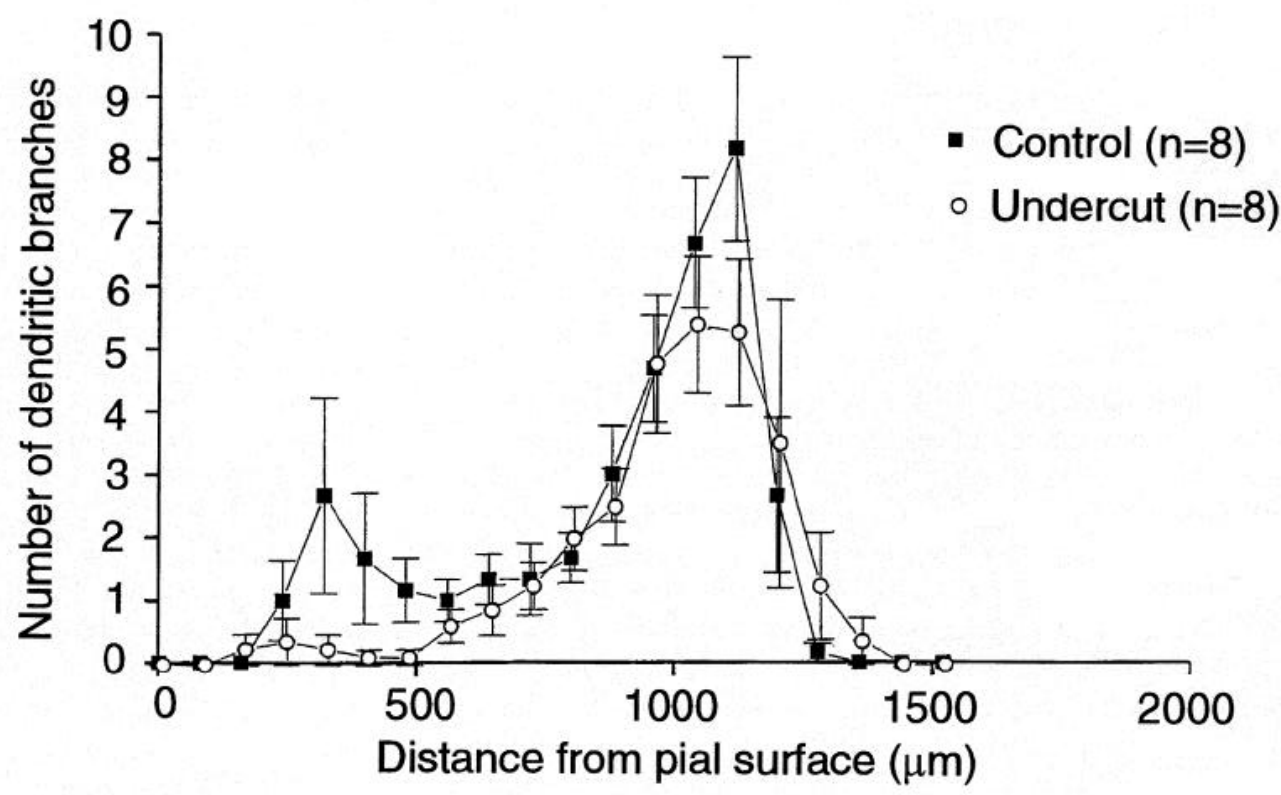


contact that have structural differences from those in control neurons. Results of one electron microscopic study in chronically isolated cat cortex provided evidence for synaptic plasticity with increased numbers of symmetrical synapses on dendritic shafts (Rutledge, 1978), although earlier experiments had failed to reveal signs of new synapses (Szentagothai, 1965; Gruner et al., 1974). A morc recent study of mature rat cortex following knife cuts revealed development of growth cones within $4 \mathrm{~d}$, and what were interpreted as newly formed asymmetrical synapses by $16 \mathrm{~d}$ postlesion (Maxwell et al., 1990).

Studies of synapses in epileptic human hippocampus (Babb et al., 1991; Mathern et al., 1994) and rat hippocampus following entorhinal cortex lesions (Anthes et al., 1993) have shown newly formed synapses that can have smaller components than already existing ones, including smaller boutons (but see Chen and Hillman, 1990). It has been suggested that there is a relationship between the number of synaptic contacts that a neuron makes and the size of postsynaptic densities so that, with reorganization induced by injury or other processes, an increase in the numbers of synaptic contacts would be associated with a decrease in the postsynaptic area of each one (Hillman and Chen, 1984; Sabel and Schneider, 1988). The layer V pyramidal neurons studied here have lost their subcortical projection field and have generated more than twice as many presumed intracortical synaptic contacts as control neurons (Fig. 3C). It is interesting to speculate whether the small size of the axonal swellings reflects a decrease in postsynaptic area that offsets the increased number of intracortical synapses of each neuron.

The functional consequences of sprouting of layer $\mathrm{V}$ pyramidal axonal arbors are hard to assess without knowing the targets of the presumed new synaptic contacts. It is of interest that the topographic pattern of axonal arbors in neurons that are presumably undergoing a sprouting reaction is similar to that seen in control cells (e.g., Fig. 6). This suggests that these injured neurons may have the same distribution of intracortical postsynaptic targets, albeit more of them. These changes in connectivity may be, in a sense, adaptive and provide an anatomic substrate for some of the recovery and reorganization of cortical function that may occur after cortical trauma or stroke (e.g., Jenkins and Merzenich, 1987; Weiller et al., 1993). On the other hand, the presumed increase in connectivity may also be maladaptive; epileptogenesis in the chronically injured cortex (e.g., Fig. 1) could be related, at least in part, to increased excitatory synaptic coupling in layer V. Activities in this lamina are important for epileptogenesis, since in both chronically injured cortex (Hoffman ct al., 1994), and in "normal" cortical slices treated with convulsant drugs (Connors, 1984; Hoffman and Prince, 1995), interictal epileptiform discharges are initiated at this site. Hyperexcitability in chronically isolated kitten cortex studied in vivo also appeared to be initiated in deeper cortical layers (Purpura and Housepian, 1961). The results of the present experiments demonstrate axonal sprouting in layer $\mathrm{V}$ pyramidal neurons whose excessive symaptic activity marks them as participants in epileptiform discharges. It is important to note, however, that a causal relationship between sprouting and epileptogenesis has yet to be established in either neocortex or hippocampus.

Modeling of populations of CA3 neurons in hippocampus (Traub and Wong, 1982) indicates that the density of recurrent excitatory connections is a critical factor in epileptogenesis. To date there has been no quantitative assessment of monosynaptic excitatory and inhibitory synaptic events in layer $\mathrm{V}$ of chronically isolated cortex to test the hypothesis that the anatomic findings reported here have functional consequences. Certainly other injury-induced alterations, such as changes in intrinsic membrane properties of pyramidal neurons (Prince and Tseng, 1993; Tseng and Prince, unpublished observations), could contribute to the hyperexcitability of partially isolated cortex. However, if most of the presumed new synapses in layer $\mathrm{V}$ are made onto excitatory (pyramidal) neurons, as is the case normally for existing pyramidal cell contacts (Kisvarday et al., 1986; Gabbott et al., 1987), a significant amount of new recurrent excitatory circuitry would be available to synchronize the population and perhaps generate epileptiform activities of the sort shown in Figure 1 . Single pyramidal neurons might contact more postsynaptic cells, or increase the number of contacts onto a given target. In this context, it is interesting to note that multiple extracellular unit recordings in chronically isolated cortex of implanted unanesthetized cats show increased synchronization between neighboring neurons (Burns et al., 1979). New excitatory synapses from sprouting pyramidal cell axons onto interneurons might also be generated following the injury and increase inhibitory electrogenesis, perhaps contributing to the prominent inhibitory currents that occur during interictal discharges (Fig. $1 B)$. The fact that epileptogenesis occurs, however, suggests that enhanced synaptic excitation of pyramidal neurons predominates, as is the case in hippocampal slices treated with 4-aminopyridine where both excitatory and inhibitory synaptic currents are augmented (Rutecki et al., 1987).

\section{References}

Anthes DI, I.eBoutillier IC, Petit TL (1993) Structure and plasticity of newly formed adult synapses: a morphometric study in the rat hippocampus. Brain Res 626:50-62.

Babb TL, Kupfer WR, Pretorius JK, Crandall PH, Levesque MF (1991) Synaptic reorganization by mossy fibers in human epileptic fascia dentata. Neuroscience 42:351-363.

Babb TL, Pretorius JK, Kupfer WR, Mathern GW, Crandall PH, Levesque MF (1992) Aberrant synaptic reorganization in human epileptic hippocampus: evidence for feedforward excitation. Dendron 1:725.

Bird SJ, Aghajanian GK (1975) Denervation supersensitivity in the cholinergic septo-hippocampal pathway: a microiontophoretic study. Brain Res 100:355-370.

Blanton MG, Lo Turco JJ, Kriegstein AR (1989) Whole cell recording from neurons in slices of reptilian and mammalian cerebral cortex. J Neurosci Methods 30:203-210.

Burkhalter A, Charles V (1990) Organization of local axon collaterals of efferent projection neurons in rat visual cortex. J Comp Neurol 302:920-934.

Burns BD, Webb FR, Webb AC (1979) The correlation between discharge times of neighbouring neurons in isolated cerebral cortex. Proc R Soc Lond [Biol] 203:347-360.

Chagnac-Amitai Y, Luhmann HJ, Prince DA (1990) Burst generating and regular spiking layer 5 pyramidal neurons of rat neocortex have different morphological features. J Comp Neurol 296:598-613.

Chen S, Hillman DE (1990) Robust synaptic plasticity of striatal cells following partial deafferentation. Brain Res 520:103-114.

Connors BW (1984) Initiation of synchronized neuronal bursting in ncocortcx. Nature 310:685-687.

Cronin J, Dudek FE (1988) Chronic seizures and collateral sprouting of dentate mossy fibers after kainic acid treatment in rats. Brain Res 474:181-184.

Darian-Smith C, Gilbert CD (1994) Axonal sprouting accompanies functional reorganization in adult cat striate cortex. Nature 368:737740.

Dragunow M, Goulding M, Faull RL, Ralph R, Mee E, Frith R (1990) Induction of c-fos mRNA and protein in neurons and glia after traumatic brain injury: pharmacological characterization. Exp Neurol 107:236-248.

Dunn-Meynell AA, Benowitz LI, Levin BE (1992) Vibrissectomy in- 
duced changes in GAP-43 immunoreactivity in the adult rat barrel cortex. J Comp Neurol 315:160-170.

Echlin FA (1959) The supersensitivity of chronically "isolated" ccrcbral cortex as a mechanism in focal epilepsy. Electroencephalogr Clin Neurophysiol 11:697-722.

Echlin FA, Battista A (1963) Epileptiform seizures from chronic isolated cortex. Arch Neurol 9:154-170.

Ernfors P, Bengzon, J, Kokaia Z, Persson H, Lindvall O (1991) Increased levels of messenger RNAs for neurotrophic factors in the brain during kindling epileptogenesis. Neuron 7:165-176.

Fishman PS, Mattu A (1993) Fate of severed cortical projection axons. J Neurotrauma 10:457-470.

Fukuda A, Prince DA (1992) Excessive intracellular $\mathrm{Ca}^{2+}$ inhibits glutamate-induced $\mathrm{Na}^{+}-\mathrm{K}^{+}$pump activation in rat hippocampal neurons. J Neurophysiol 68:28-35.

Gabbott PL, Martin KA, Whitteridge D (1987) Connections between pyramidal neurons in layer 5 of cat visual cortex (area 17). $J$ Comp Neurol 259:364-381.

Gall CM (1992) Regulation of brain neurotrophin expression by physiological activity. Trends Pharmacol Sci 13:401-403.

Gall CM (1993) Seizure-induced changes in neurotrophin expression: implications for epilepsy. Exp Neurol 124:150-166.

Gruner JE, Hirsch JC, Sotelo C (1974) Ultrastructural features of the isolated suprasylvian gyrus of the cat. J Comp Neurol 154:1-28.

Halpern LM (1972) Chronically isolated aggregates of mammalian cerebral cortical neurons studied in situ. In: Experimental models of epilepsy - a manual for the laboratory worker (Purpura DP, Penry JK, Tower D, Woodbury DM, Walter R, eds), pp 197-221. New York: Raven.

Havton L, Kellerth JO (1987) Regeneration by supernumerary axons with synaptic terminals in spinal motoneurons of cats. Nature 325: $711-714$

Herdegen T, Sandkuhler J, Gass P, Kiessling M, Bravo R, Zimmermann (1993) M JUN, FOS, KROX, and CREB transcription factor proteins in the rat cortex: basal expression and induction by spreading depression and epileptic seizures. J Comp Neurol 333:27I-288.

Hillman DE, Chen S (1984) Reciprocal relationship between size of postsynaptic densities and their number: constancy in contact area. Brain Res 295:325 343.

Hoffman SN, Prince DA (1995) Epileptogenesis in immature neocortical slices induced by 4-aminopyridine. Brain Res 85:64-70.

Hoffman SN, Salin PA, and Prince DA (1994) Chronic neocortical epileptogenesis in vitro. J Neurophysiol 71:1762-1773.

Horikawa K, Armstrong WE (1988) A versatile means of intracellular labeling: injection of biocytin and its detection with avidin conjugates. J Neurosci Methods 25:1-11.

Ihara I (1988) Massive somatodendritic sprouting of cortical neurons in Alzheimer's disease. Brain Res 459:138-144.

Isokawa M, Levesque MF, Babb TL, Engel J Jr (1993) Single mossy fiber axonal systems of human dentate granule cells studied in hippocampal slices from patients with temporal lobe epilepsy. J Neurosci 13:1511-1522.

Jenkins WM, Merzenich MM (1987) Reorganization of neocortical representations after brain injury: a neurophysiological model of the bases of recovery from stroke. Prog Brain Res 71:249-266.

Jones TA, Schallert T (1992) Overgrowth and pruning of dendrites in adult rats recovering from neocortical damage. Brain Res 581:156160.

Keller A, Arissian K, Asanuma H (1990) Formation of new synapses in the cat motor cortex following lesions of the deep cerebellar nuclei. Fxp Brain Res 80:23-33.

Kisvarday ZF, Martin KA, Freund TF, Magloczky Z, Whitteridge D, Somogyi P (1986) Synaptic targets of HRP-filled layer III pyramidal cells in the cat striate cortex. Exp Brain Res 64:541-552.

Kuang RZ, Kalil K (1990) Specificity of corticospinal axon arbors sprouting into denervated contralateral spinal cord. J Comp Neurol 302:461-472.

Lagerback PA, Ronnevi, LO, Cullheim, S, Kellerth JO (1981) An ultrastructural study of the synaptic contacts of alpha-motoneurone axon collaterals. I. Contacts in lamina IX and with identified alphamotoneurone dendrites in lamina VII. Brain Res 207:247-266.

Lapchak PA, Araujo DM, Hefti F (1993) BDNF and trkB mRNA expression in the rat hippocampus following entorhinal cortex lesions. Neuroreport 4:191-194.

Larkman A, Mason A (1990) Correlations between morphology and electrophysiology of pyramidal neurons in slices of rat visual cortex I. Establishment of cell classes. J Neurosci 10:1407-1414.

Liu CN, Chambers WW (1958) Intraspinal sprouting of dorsal root axons. Arch Neurol Psych 79:46-61.

Lynch GS, Cotman CW (1975) The hippocampus as a model for studying anatomical plasticity in the adult brain. In: Hippocampus (Isacson RL, Probram KH, eds), pp 123-155. New York: Plenum.

Lynch G, Deadwyler S, Cotman G (1973) Postlesion axonal growth produces permanent functional connections. Science 180:1364-1366.

Masliah E, Mallory M, Ge N, Godson C, Saitoh T (1993) Phorbol ester-induced neuritic alterations in the rat neocortex. Structural and immunocytochemical studies. Mol Chem Neuropathol 20:125-145.

Masukawa LM, Uruno K, Sperling M, O'Connor MJ, Burdette LJ (1992) The functional relationship between antidromically evoked field responses of the dentate gyrus and mossy fiber reorganization in temporal lobe epileptic patients. Brain Res 579:119-127.

Mathern GW, Leite JP, Pretorius JK, Quinn B, Peacock WJ, Babb TL (1994) Children with severe epilepsy: evidence of hippocampal neuron losses and aberrant mossy fiber sprouting during postnatal granule cell migration and differentiation. Dev Brain Res 78:70-80.

Matthews DA, Cotman C, Lynch G (1976) An electron microscopic study of lesion-induced synaptogenesis in the dentate gyrus of the adult rat. II. Reappearance of morphologically normal synaptic contacts. Brain Res 115:23-41.

Maxwell WL, Follows R, Ashhurst DE, Berry M (1990) The response of the cerebral hemisphere of the rat to injury. I. The mature rat Philos Trans R Soc Lond [Biol] 328:479-500.

Mello LEAM, Cavalheiro EA, Tan AM, Kupfer WR, Pretorius JK, Babb, TL, Finch DM (1993) Circuit mechanisms of seizures in the pilocarpine model of chronic epilepsy: cell loss and mossy fiber sprouting. Epilepsia 34:985-995.

Merlio JP, Ernfors P, Kokaia Z, Middlemas DS, Bengzon J, Kokaia M, Smith ML, Siesjo BK, Hunter T, Lindvall O, Persson H (1993) Increased production of the TrkB protein tyrosine kinase receptor after brain insults. Neuron 10:151-164.

Mikucki SA, Oblinger MM (1991) Corticospinal neurons exhibit a novel pattern of cytoskeletal gene expression after injury. J Neurosci Res 30:213-225

Nitsch R, Frotscher M (1991) Maintenance of peripheral dendrites of GABAergic neurons requires specific input. Brain Res 554:304-307.

Ojima H, Honda CN, Jones EG (1992) Characteristics of intracellularly injected infragranular pyramidal neurons in cat primary auditory cortex. Cereb Cortex 2:192-216.

Prince DA, Tseng G-F (1993) Epileptogenesis in chronically injured cortex: in vitro studies. J Neurophysiol 69:1276-1291.

Purpura DP, Housepian EM (1961) Morphological and physiological properties of chronically isolated immature neocortex. Exp Neurol $4: 377-401$.

Raisman G (1969) Neuronal plasticity in the septal nuclei of the adult rat. Brain Res 14:25-48.

Ramon y Cajal S (1928a) Study of traumatic degeneration in the cerebral cortex. In: Degeneration and regeneration of the nervous system (May Raoul M, ed), pp 656-692. London: Oxford UP.

Ramon y Cajal S (1928b) Phenomena of aborted regeneration in the cerebral cortex. In: Degeneration and regeneration of the nervous system (May Raoul M, ed), pp 693-703. London: Oxford UP.

Reiffenstein RJ, Triggle C (1972) Sensitivity of denervated cerebral cortex to cholinomimetics. Electroencephalogr Clin Neurophysiol 33: 215-220.

Represa A, Jorquera I, Le Gal La Salie G, Ben-Ari Y (1993) Epilepsy indiced collateral sprouting of hippocampal mossy fibers: does it induce the development of ectopic synapses with granule cell dendrites? Hippocampus 3:257-268.

Ribak CE, Reiffenstein RJ (1982) Selective inhibitory synapse loss in chronic cortical slabs: a morphological basis for epileptic susceptibility. Can J Physiol Pharmacol 60:864-870.

Rutecki PA, Lebeda FJ, Johnston D (1987) 4-Aminopyridine produces epileptiform activity in hippocampus and enhances synaptic excitation and inhibition. J Neurophysiol 57:1911-1924.

Rutledge LT (1978) The effects of denervation and stimulation upon synaptic ultrastructure. J Comp Neurol 178:117-128.

Rutledge LT, Duncan J, Beatty N (1969) A study of pyramidal cell axon collaterals in intact and partially isolated adult cerebral cortex. Brain Res 16:15-22.

Rutledge LT, Duncan J, Cant N (1972) Long-term status of pyramidal 
cell axon collaterals and apical dendritic spines in denervated cortex. Brain Res 41:249-262.

Sabel BA, Schneider GE (1988) The principle of "conservation of total axonal arborizations": massive compensatory sprouting in the hamster subcortical visual system after early tectal lesions. Exp Brain Res 73:505-518.

Salin PA, Parada I, Hoffman SN, Tseng G-F, Prince DA (1993) Axonal sprouting of adult rat neocortical pyramidal cells in chronic epileptogenic lesions. Soc Neurosci Abstr 19:1031.

Sharp JW, Sagar SM, Hisanaga K, Jasper P, Sharp FR (1990) The NMDA receptor mediates cortical induction of fos and fos-related antigens following cortical injury. Exp Neurol 109:323-332.

Sharpless SK (1964) Reorganization of function in the nervous systemuse and disuse. Annu Rev Pliysiol 26:357-388.

Sharpless SK, Halpern LM (1962) The electrical excitability of chronically isolated cortex studied by means of permanently implanted electrodes. Electroencephalogr Clin Neurophysiol 14:244-255.

Sholl DA (1956) The quantification of neuronal connectivity. In: The organization of the cerebral cortex (Sholl DA, ed), pp 43-65. London: Methuen.

Sutula T, He XX, Cavazos J, Scott G (1988) Synaptic reorganization in the hippocampus induced by abnormal functional activity. Science 239:1147-1150.

Sutula TP, Golarai G, Cavazos J (1992) Assessing the functional significance of mossy fiber sprouting. Epilepsy Res Suppl 7:251-259.

Szentagothai J (1965) The synapses of short local neurons in the cerebral cortex. Symp Biol Hung 5:251-276.
Tauck DL, Nadler JV (1985) Evidence of functional mossy fiber sprouting in hippocampal formation of kainic acid treated rats. J Neurosci 5:1016-1022.

Tetzlaff W, Alexander SW, Miller FD, Bisby MA (1991) Response of facial and rubrospinal neurons to axotomy: changes in mRNA expression for cytoskeletal proteins and GAP-43. J Neurosci 11:25282544.

Traub RD, Wong RK (1982) Cellular mechanism of neuronal synchronization in epilepsy. Science 216:745-747.

Tseng G-F, Prince DA (1993) Heterogeneity of rat corticospinal neurons. J Comp Neurol 335:92-108.

Tseng G-F, Parada I, Prince DA (1991) Double-labelling with rhodamine beads and biocytin: a technique for studying corticospinal and other projection neurons in vitro. J Neurosci Methods 37:121-131.

Tsukahara N, Hultborn H, Murakami F, Fujito Y (1975) Electrophysiological study of formation of new synapses and collateral sprouting in red nucleus neurons after partial denervation. J Neurophysiol 38 : 1359-1372.

Villablanca JR, Gomez-Pinilla F, Sonnier BJ, Hovda DA (1988) Bilateral pericruciate cortical innervation of the red nucleus in cats with adult or neonatal cerebral hemispherectomy. Brain Res 453:17-31.

Weiller C, Ramsay SC, Wise RJ, Friston KJ, Frackowiak RS (1993) Individual patterns of functional reorganization in the human cerebral cortex after capsular infarction. Ann Neurol 33:181-189.

Westenbroek RE, Westrum LE, Hendrickson AE, Wu JY (1988) Ultrastructure of synaptic remodeling in piriform cortex of adult rats after neonatal olfactory bulb removal: an immunocytochemical study. $\mathrm{J}$ Comp Neurol 274:334-346. 